\title{
Does Quality Matter? A Study on Customer Expectation in Motorcycle Repair Provider in Surabaya, Indonesia
}

\author{
Dhyah Harjanti ${ }^{1 *}$, Edbert Karlison Theodore ${ }^{1}$, and Shahzad $\mathrm{Ali}^{2}$ \\ ${ }^{1}$ Department of Management, Faculty of Business and Economics, Petra Christian University, \\ Jl. Siwalankerto 121-131, Surabaya 60236, Indonesia. \\ ${ }^{2}$ International Islamic University Islamabad, H-10, Islamabad, \\ Islamabad Capital Territory 44000, Pakistan
}

\begin{abstract}
Motorcycle has become a common vehicle in Indonesia due to its flexibility to drive around in various geographical terrain. The number of motorcycle purchases in Indonesia is increasing annually, along with the repair services and spare part selling. Abundant repair service providers create fierce competition among themselves, so many providers maintain their service quality in order to retain their customer. The aim of this research is to investigate the impact of service quality and relationship quality to customer satisfaction in motorcycle repair providers. This research is using the quantitative approach, in which the data are collected by questionnaires distributed to samples of populations. The population is the customers who have purchased repair services and spare parts for their motorcycle, and the number of samples is 100 respondents. The data are analyzed with a SmartPLS software, and the results show a positive significant impact from service quality to customer satisfaction, a positive significant impact from service quality to relationship quality, and a positive impact from relationship quality to customer satisfaction. Therefore, for the long term competitive advantage, motorcycle repair service providers have to consider their service quality and relationship quality to retain their customers.
\end{abstract}

Keywords: Customer satisfaction, relationship quality, service quality.

\section{Introduction}

A maintenance and repair shop is needed by the motorcycle users because it helps them to maintain their vehicle. This makes every shop competing to give the best to satisfy their customers. Customer satisfaction is the key and the benchmark to make a business goes well and develops. One thing that influences customer satisfaction is the given service quality [1].

Good service quality is fundamental for business owner to develop the business. The lack of awareness of the importance of service quality makes the spare part owner gives the perfunctory service. However, the good service gives positive value and benefits to

*Corresponding author: dhyah@petra.ac.id 
consumers. The satisfactory service is the way to compete between the business owners to show how good their quality is.

Another way to improve the service quality is by providing skillful employees and adequate facilities. If the customers feel the service quality is good, therefore the customers will be comfortable and trust the service provider to give what they want. As a result, there is a relationship between the service provider and customer. If the relationship quality between them is good, the customer will be satisfied with the given service. The good service quality will create relationship quality to the customers therefore by the good relationship quality, the customers will be satisfied with the given service.

According to Grönroos, relationship quality is a process to shape the quality in a relationship with the customers where it becomes the customers' view of the developing quality over time [2]. Ndubisi and Wah say that there are five dimensions to measure relationship quality; they are trust, competency, commitment, communication and conflict handling [3]. These five dimensions are factors that determine relationship quality influencing the customer satisfaction level. This is in line with the research of Tohidinia and Haghighi that says that the relationship quality becomes an important aspect in increasing the level of customer satisfaction [4].

According to Simamora, service quality is an effort to fulfill the customer's need and want in delivering what they hope. Service quality has benefits resulted from the service to increase the buying [5]. There are five dimensions of service quality according to Parasuraman, they are reliability, responsiveness, assurance, empathy and tangible [6]. These dimensions are the measurements to determine the level of the given service quality. The research of Izogo and Ogba study that the customers is satisfied when the service fulfills the need as wanted [7].

Customer satisfaction definition according to Zeithaml et al., is a response from customer that contains evaluation of product features or service, or the product or the service give the level of customer satisfaction [8]. If the customer feels satisfied with the product or service, they tend to repurchase at the same place. Therefore, service quality increasing in a company is needed to give the customers satisfaction as they hoped.

The competition in motorcycle's sparepart and repairing business is tight. This happens because in one area there are a lot of same shops. This makes the owners have to have a distinction to attract the customers, such as in giving the best service. They put their effort to give the best quality service to create a good relationship and to give satisfaction for their customers. This relationship is to make the customer trust and certain to the shop. It is done by giving friendly welcome to customers, providing snacks, drinks, television and seats for them to wait for the services. Some of the shops also provide picking and delivery for reachable customers or even lending their motorcycle for free if the customers have trouble or if the service takes time to do. They also give a certain price discount to customer who already bought some products and did repairment more than twice. In addition, these shops also increase the skills of their employees to be more handy, skillful and understanding when responding to customers' problems. It is done to give advantages to both shop and customers. The customers will be satisfied by the service when visiting the shop. Based on the phenomena, this research is aimed to study the influence of service quality toward customer satisfaction through relationship quality in motorcycle repair providers in Surabaya. 


\subsection{The relationship between concept and hypothesis of the research}

\subsubsection{The service quality and customer satisfaction}

According to Famiyeh, Kwarteng and Asante, service quality that consists of five dimensions such as reliability, responsiveness, assurance, empathy and tangibles have significant influence that can increase customer satisfaction [1]. These five dimensions is used to see the given service quality to the customers. When the service quality fulfills the need of the customers, they will be satisfied. This is supported by Izogo and Ogba, they say that service quality gives significant influence to customer satisfaction [7]. When customers are given the good service quality, they will be satisfied because what they hoped is fulfilled. In this aspect, it shows that every organization that wants to satisfy their customers have to increase their service quality.

$\mathrm{H}_{1}$ : Service Quality influences towards Customer Satisfaction in motorcycle repair providers in Surabaya.

\subsubsection{The service quality and relationship quality}

The research of $\mathrm{Yu}$ and Tung explains that the better the service quality, the higher the the relationship quality of the company and the customer [9]. If the company is able to strengthen or increase the quality in communicating and offering additional services, it will create a good service. A company should give efforts to understand more of the customer's need to fulfill it better. It is important to overcome the customers' problems effectively. Other than building communication, a company should keep an open mind for all the complaints and actively improving as needed.

In the research by Giovanis et al., service quality influences significantly to relationship quality [10]. This research shows that relationship quality is viewed as overall assessment from relationship power and how far the relationship fulfills the need and hope of each side. It can be seen when the customers receive better service quality and treated equally to the other customers, the result is higher relationship quality with the service provider and customers will go back to that place.

$\mathrm{H}_{2}$ : Service Quality influences Relationship Quality in motorcycle repair providers in Surabaya.

\subsubsection{The relationship quality with customer satisfaction}

In the research of Tohidinia and Haghighi, relationship quality influences significantly to customer satisfaction. Relationship quality is the main focus for companies because by paying attention to relationship quality, it means to make the customers as the main priority [4]. The good relationship quality between seller and customer that includes trust, commitment, communication and conflict handling increases impact and benefits for company short and long term. Relationship quality becomes the important aspect in anticipating when a company needs to know if the need of the customer is fulfilled. The company has to increase relationship quality with the customers to increase their satisfaction. This means that relationship quality influences customer satisfaction.

$\mathrm{H}_{2}$ : Relationship Quality influences Customer Satisfaction in motorcycle repair providers in Surabaya. 


\subsection{Research framework}

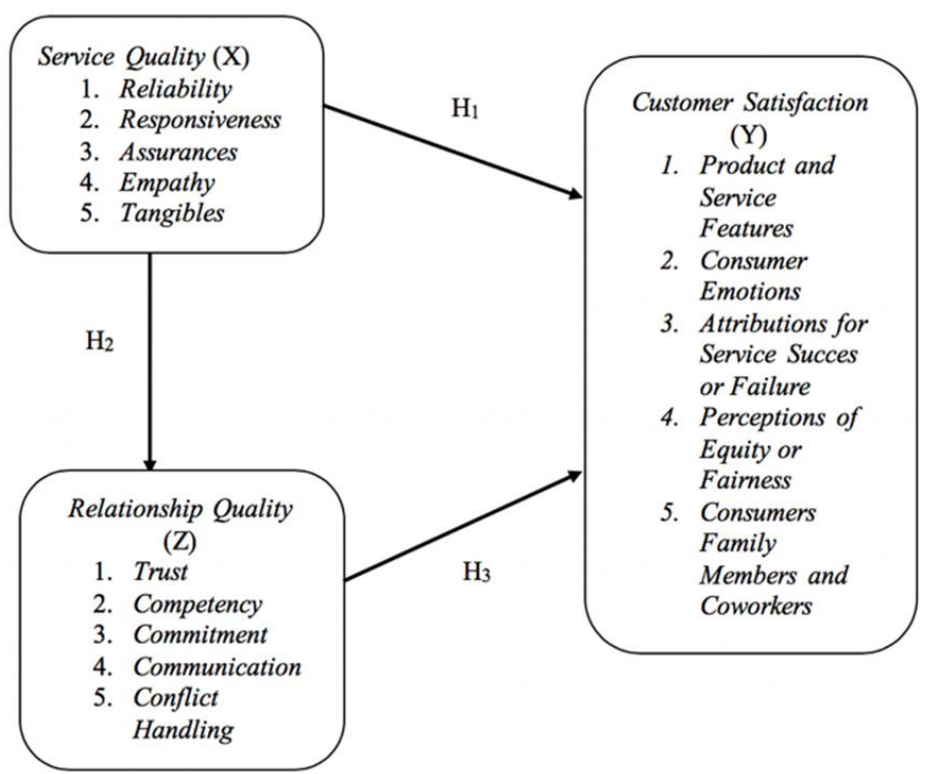

Fig. 1. Research framework

Service quality influences relationship quality, which is named $\mathrm{H}_{1}$, where the better the service quality the higher the relationship quality. $\mathrm{In}_{2}$ relationship quality influences customer satisfaction. In $\mathrm{H}_{3}$, the service quality influences customer satisfaction.

\section{Methodology}

\subsection{Type of research}

This research uses causal quantitative method. According to Sugiyono, this approach studies the relationship between variables that has cause and effect [11]. This research tests the determined hypothesis to look for the influence between independent variables (the influencing variables) with the dependent variables (the impacted variables). The object of this research are service quality, relationship quality and customer satisfaction in motorcycle repair providers in Surabaya.

\subsection{Population dan sample}

\subsubsection{Population}

Population in this research is all the customers who bought and/or do repairment in motorcycle repair providers in Surabaya for more than twice in past 6 mo. It is chosen because the customers who bought or do repairment more than twice likely understand the service criteria by motorcycle repair providers in Surabaya. 


\subsubsection{Sample}

The technique used to do sampling in this research is non probability sampling. Sugiyono explains that this sampling technique does not give opportunity to every element or population to be chosen as a sample [11].

The method used is purposive sampling. According to Sugiyono, this sampling is done by certain determination [11]. This research determines some sampling criteria. Some criteria are the customer's minimum age is $17 \mathrm{yr}$ old, because it is the age that is categorized to understand the questionnaire and the products of motorcycle spareparts, and the other criteria is that the customer have bought or done repairment for more than three times in motorcycle repair providers in Surabaya in the period of 6 mo.

Samples are 100 respondents that are customers who have used the products and service of motorcycle repair providers in Surabaya.

\subsection{Data collection method}

Data collection method in this research is collected through questionnaire. Questionnaire is a technique in collecting data done by giving a set of written questions to respondents to answer. Questionnaire is given when purchasing or waiting for the repair in motorcycle repair providers.

The questionnaire is using Likert scale. According to Sugiyono, Likert scale is a scale used to measure the attitude, opinion and perception of individuals or groups about social phenomenon [11].

\subsection{Data analysis technique}

\subsubsection{Partial Least Square (PLS)}

PLS is a powerful analysis method because it can be done in all data, and the sample size does not require big size [12]. PLS can be used as a confirmation theory and a connection builder that has no theoretical basis yet or proposition examination. PLS is also used for structural modeling with indicator that is reflective or formative. Indicator used in this research is reflective. Reflective indicator is an indicator that is reflecting, presenting, and observing the impact from the latent variable [12].

\subsubsection{Outer model testing}

The outer model testing is used to define the relationship between indicators and the construct [12]. There are three outer model tests used in this research, they are convergent validity, criminant validity and composite validity.

\subsubsection{Inner model testing}

Structural model in PLS is evaluated by $\mathrm{R}^{2}$ for dependent construct and T-test to test the signifying of coefficient in structural track. $\mathrm{R}^{2}$ value is used to measure the influence of certain independent value to dependent variable. The result of $\mathrm{R}^{2}$ is $0.67,0.33$ and 0.19 . The higher $\mathrm{R}^{2}$ shows that the better structural model.

PLS model is evaluated using $\mathrm{Q}^{2}$ to measure how good the observation value resulted by model and the estimated parameters. If $\mathrm{Q}^{2}>0$, it shows that model has predictive relevant, but if $\mathrm{Q}^{2}<0$ it shows that model has less predictive relevant value. 


\section{Analysis and discussion}

\subsection{Average Variance Extracted (AVE)}

Table 1. The result of AVE test

\begin{tabular}{ll}
\hline & AVE \\
\hline Service Quality & 0.549 \\
Customer Satisfaction & 0.659 \\
Relationship Quality & 0.583 \\
\hline
\end{tabular}

Source: Processed data

Based on Table 1 on service quality, relationship quality and customer satisfaction variables, the value is $>0.5$ and it is stated to be valid.

\subsection{Inner model evaluation}

Table 2. R-Square

\begin{tabular}{lc}
\hline & R Square \\
\hline Relationship Quality & 0.738 \\
Customer Satisfaction & 0.711 \\
\hline Source: Processed data &
\end{tabular}

Table 2 shows that the R-square result of relationship quality is 0.738 . This means that service quality influences relationship quality $73.8 \%$, the rest is $26.2 \%$ influenced by other variables outside the research. The R-square result of customer satisfaction is 0.711 . It shows that service quality and relationship quality can influence customer satisfaction $71.1 \%$. The rest $28.9 \%$ comes from the other variables outside the research.

Goodness of fit value in PLS model can be known through Stone - Geisser $\left(Q^{2}\right)$. This test is used to measure how good the observation resulted by the model and the estimated parameters. $\mathrm{Q}^{2}$ can be measured with the following equation:

$$
\begin{aligned}
\mathrm{Q}_{2} & =1-\left(1-\mathrm{R}^{2} \text { Relationship Quality }\right) \times\left(1-\mathrm{R}^{2} \text { Customer Satisfaction }\right) \\
& =1-(1-0.738) \times(1-0.711) \\
& =1-(0.262 \times 0.289) \\
& =0.9243
\end{aligned}
$$

Q square value in this research is 0.924 that means the observation value is $92.4 \%$. It can be said that this research has a good goodness of fit.

\subsection{Hypothesis testing}

Hypothesis testing is done by observing the t-statistic and the influence of coefficient (original sample estimate). The hypothesis of the research is accepted if t-statistic >1.96. The following figure is the result of the influence of coefficient and t-statistic: 


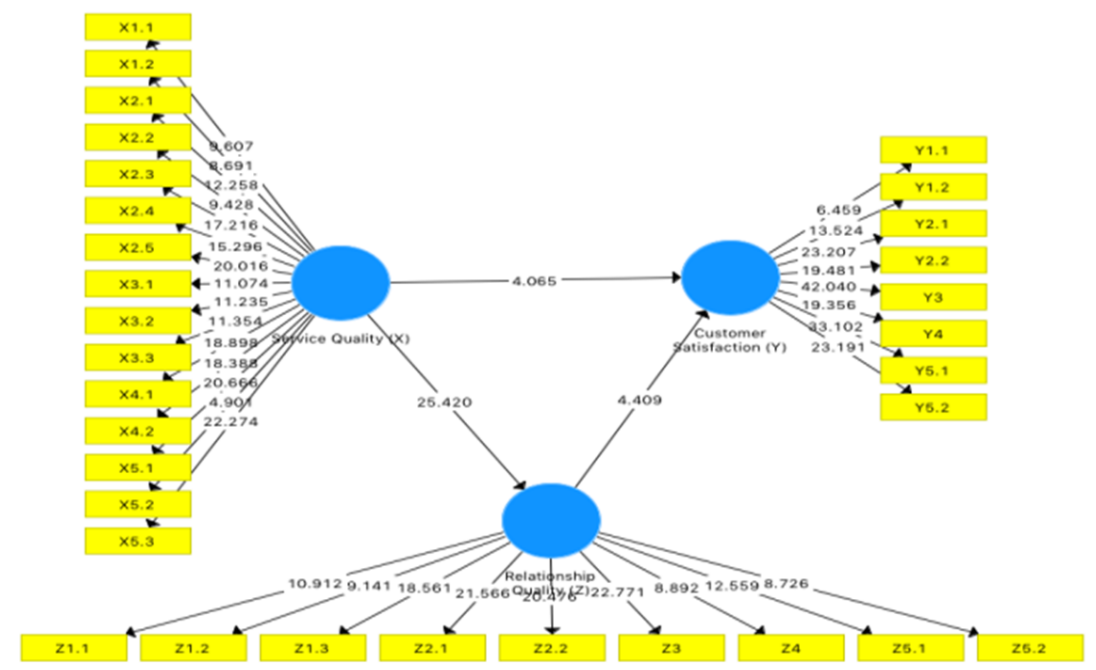

Fig. 2. Inner model

Source: Processed data

The result of path coefficient value can be explained as follows:

Table 3. The result of path coefficients value

\begin{tabular}{lcc}
\hline & $\begin{array}{c}\text { Path } \\
\text { Coefficient }\end{array}$ & t-statistics \\
\hline Service Quality $(\mathbf{X}) \rightarrow$ Customer Satisfaction (Y) & 0.437 & 4.065 \\
Service Quality $(\mathbf{X}) \rightarrow$ Relationship Quality (Z) & 0.859 & 25.420 \\
Relationship Quality $(\mathbf{Z}) \rightarrow$ Customer Satisfaction $(\mathbf{Y})$ & 0.437 & 4.409 \\
\hline
\end{tabular}

Source: Processed data

The influence of service quality $(X)$ toward relationship quality $(Z)$ resulting t-statistic $25.420>1.96$. It can be concluded that service quality influences significantly toward relationship quality in motorcycle repair providers. $\mathrm{H}_{1}$ pressumes that service quality influences toward relationship quality, this hypothesis can be accepted. The influence of service quality toward relationship quality influences positively that shows by the result of coefficient influence 0.859 .

The influence of relationship quality $(\mathrm{Z})$ toward customer satisfaction $(\mathrm{Y})$ resulting $\mathrm{t}$ statistic $4.409>1.96$. It can be concluded that relationship quality influences significantly toward customer satisfaction in motorcycle repair providers in Surabaya. $\mathrm{H}_{2}$ presumes that relationship quality influences toward customer satisfaction, this hypothesis can be accepted. The relationship quality influences positively toward customer satisfaction that is shown by the result of the influence of coefficient 0.437 .

The influence of service quality $(\mathrm{X})$ toward customer satisfaction $(\mathrm{Y})$ resulting t-statistic $4.065>1.96$. It can be concluded that service quality is significantly toward customer satisfaction in motorcycle repair providers in Surabaya. $\mathrm{H}_{3}$ presumes that service influences toward customer satisfaction, this hypothesis can be accepted. The influence of service quality toward customer satisfaction has positive influence shown by the result of coefficient influence 0.437 .

The result about indirect influence is explained as follows: 
Table 4. Indirect Influence

\begin{tabular}{lc}
\hline \multicolumn{1}{c}{ Influence } & Coefficient Influence \\
\hline Service Quality $(\mathrm{X}) \rightarrow$ Relationship Quality $(\mathrm{Z})$ & $0.859 \times 0.437=0.3753$ \\
$\rightarrow$ Customer Satisfaction $(\mathrm{Y})$ & \\
\hline Source: Processed data &
\end{tabular}

Table 4 shows that the indirect influence between service quality 0.375 toward customer satisfaction through relationship quality is 0.375 , smaller than the direct influence that is 0.437 . This shows that the indirect relationship is not as big as the direct influence.

\subsection{Discussion}

The majority of 100 respondents of motorcycle repair providers in Surabaya consists of male $69 \%$, age of $26 \mathrm{yr}$ old to $35 \mathrm{yr}$ old $40 \%$, and work as private employee $31 \%$. Based on the average cost for maintenance and repair of motorcycle IDR 151000 to IDR 200000 , there are 34 people $(34 \%) .36$ people $(36 \%)$ knows motorcycle repair providers by recommendation of their friends. 37 people $(37 \%)$ are the customers who know this shop 3 yr to 4 yr ago.

The result of this research shows that there is significant influence between service quality toward relationship quality. The R-square of service quality influence toward relationship quality is $73.8 \%$. This is a result of a good service quality influences the good relationship quality. The R-square value of customer satisfaction that is influenced by service quality and relationship quality is $71.1 \%$.

From the result of this research, it can be explained that respondents who work as entrepreneurs, government employees and private employees are the most dominant respondents in motorcycle repair providers in Surabaya. Most of them know the shop by themselves. It is suggested that the shop put bigger billboard to make it easier to see by the passersby.

The result also shows that there is a category of respondents based on sex, male respondents feels that the given service quality is running well. Based on the type of jobs which are entrepreneurs, government employees and private employees, they feel the service quality given by the shop is running well. This is useful for the shop to quickly increase the service, so that the customers that is coming not only from entrepreneurs, government employees and private employees.

From the result of this research, it can be explained that the male respondents feel that the relationship quality is going well because the males are easy to socialize, based on the type of jobs, entrepreneurs, government employees and private employees feels relationship quality is going well. It is because the customers who work in an office or company is easier to adapt. Another suggestion to motorcycle repair providers to gain the trust of the customers is by requiring its employees to be more friendly and helpful for customers who do not understand some products.

Another result is that male respondents is satisfied to motorcycle repair providers is because the males understand more about the product or the motorcycle sparepart. Based on the type of jobs, the respondents who are easier to be satisfied are the customer who work as entrepreneurs, government employees and private employees because they have what they need and they do not fully understand the motorcycle sparepart, therefore they are satisfied quickly. The shop is suggested to give more of its service and providing a quality product so the customer receives the benefit when purchasing and or doing motorcycle maintenance or repair. If they are satisfied they will recommend the shop to their friends or family. 


\subsubsection{Service quality influences toward relationship quality}

From the result of the research, it is known that service quality influences significantly toward relationship quality that can be seen from t-statistic. The t-statistic value is $25.420>1.96$ and path coefficient is 0.859 that is positive. This means that service quality influences significantly and positively toward relationship quality. This is in line with the research of $\mathrm{Yu}$ and Tung that states that the better the service quality the higher the relationship quality between the service provider and the customer [8].

The company should try to understand the customers' need to fulfill it better. When the customers feel they get good service, they will trust and certain to the company or the service provider. The trust will create the good relationship between them. This research is also in line with Giovanis et al., that state that service quality influences significantly toward relationship quality [9]. It can be seen when the customers receive the best service quality and they are treated equally, the service provider will gain trust from them. It will make the customers give their commitment to return to the service provider.

\subsubsection{Relationship quality influences toward customer satisfaction}

The result shows that relationship quality influences significantly toward customer satisfaction that can be seen from t-statistic value. T-statistic is $4.409>1.96$ and the path coefficient is 0.437 , which is a positive value. This means that relationship quality influences significantly and positively toward customer satisfaction. This is in line with the research of [13]. They state that relationship quality influences significantly toward customer satisfaction. Relationship quality is the main focus of most companies because by paying attention to relationship quality, it makes the customers as the main priority. If the relationship quality is good between the seller and the customers, which covers the trust, commitment, communication and conflict handling, it will produce a positive impact and benefits for the company in a short or long term. Relationship quality becomes the important aspect in observing the need of the customers, whether it is fulfilled as needed. A company should increase their relationship quality with the customers to increase the customers' satisfaction. This means that relationship quality influences positively and significantly toward customer satisfaction.

\subsubsection{Service quality influences toward customer satisfaction}

From the result of the research, it is known that service quality influences significantly toward customer satisfaction that can be seen from t-statistic value. T-statistic value is $4.065>1.96$ and path coefficient value 0.437 , which is a positive value. This means that service quality directly influences positively and significantly toward customer satisfaction. This is in line with the research of Famiyeh, Kwarteng and Asante, that states service quality consists of five dimensions: reliability, responsiveness, assurance, empathy and tangible that has significant influence to increase customer satisfaction [1]. These five dimensions are used to observe the service quality to customers. When service quality fulfills the need of the customers, they will be satisfied. It is supported by Izogo and Ogba that state service quality significantly influences toward customer satisfaction [6]. It can be seen when the customers are given a good service quality, they will be satisfied because their need is fulfilled.

\subsubsection{The influence of relationship quality as intervening variable}

From the result of the research, it is known that the amount of direct influence of service quality toward customer satisfaction is bigger than the indirect influence through relationship quality. It can be seen from the indirect influence of coefficient value, 0.3753 , smaller than the direct influence 0.437 . This shows that relationship quality is able to 
mediate service quality toward customer satisfaction, but not as big as the direct influence of service quality toward customer satisfaction.

\section{Conclusion}

This research concludes that service and relationship quality influences significantly and positively toward customer satisfaction in motorcycle repair providers in Surabaya. From the service quality variable, the indicator that has the lowest value is shop cleanliness. Therefore, motorcycle repair providers is advised to better maintain its cleanliness, for example by separating the waiting room from the repair area. The lowest value indicator in the relationship quality variable is the friendliness of the store employees. Hence motorcycle repair providers is expected to be more friendly when dealing with its customers so that customers who come can feel more comfortable when visiting the store. The lowest value indicator from customer satisfaction variable is product features provided. Motorcycle repair providers is suggested to improve the availability and variety of products to suit customer needs.

\section{References}

1. S. Famiyeh, A. Kwarteng, D. Asante-Darko, Journal of Quality in Maintenance Engineering, 24,3:262-279(2018).

https://www.emeraldinsight.com/doi/abs/10.1108/JQME-10-2016-0056

2. C. Grönroos, Service Management and Marketing: Managing The Service Profit Logic, Chichester, UK: John Wiley and Sons (2015). https://pdfs.semanticscholar.org/57b2/cf102b07e8734d07589841bb9d025d330007.pdf

3. N.O. Ndubisi, C.K. Wah, International Journal of Bank Marketing, 23,7:542557(2005). https://www.emeraldinsight.com/doi/abs/10.1108/02652320510629908

4. Z. Tohidinia, M. Haghighi, Business Strategy Series, 12,5:242-256(2011). https://www.emeraldinsight.com/doi/abs/10.1108/17515631111166889

5. B. Simamora, Panduan Riset Perilaku Konsumen, [Consumer Behavior Research Guide], Jakarta: Gramedia Pustaka Utama (2004). [in Bahasa Indonesia] https://books.google.co.id/books?id=pAfxNu7FFCYC\&dq

6. A. Parasuraman, V.A. Zeithaml, L.L. Berry, Journal of Marketing, 49,4:41-50(1985). https://journals.sagepub.com/doi/abs/10.1177/002224298504900403

7. E.E. Izogo, I.-E. Ogba, International Journal of Quality \& Reliability Management, 32,3:250-269(2015).

https://www.emeraldinsight.com/doi/abs/10.1108/IJQRM-05-2013-0075

8. V. Zeithaml, M. Bitner, M.J. Bitner, Service Marketing, Integrating Customer Focus Across the Firm, NY, USA: Mcgraw Hill (2009).

https://www.mheducation.com/highered/product/services-marketing-integratingcustomer-focus-across-firm-zeithaml-bitner/M9780078112102.html

9. T.W. Yu, F.C. Tung, Journal of Managing Service Quality, 23,2:111-130(2013). https://www.emeraldinsight.com/doi/abs/10.1108/09604521311303408

10. A. Giovanis, P. Athanasopoulou, E. Tsoukatos, Journal of Service Theory and Practice, 25,6:744-776(2015). https://www.emeraldinsight.com/doi/abs/10.1108/JSTP-11-2013-0263

11. Sugiyono. Metode Penelitian Kuantitatif Kualitatif dan R\&D, [Qualitative Quantitative Research Methods and R\&D], Bandung: Alfabeta (2012). [in Bahasa Indonesia]. http://cvalfabeta.com/product/metode-penelitian-kuantitatif-kualitatif-dan-rd-mpkk/ 
12. F. Jr. Hair, W.C. Black, B.J. Babin, R.E. Anderson, Multivariate Data Analysis:

A Global Perspective, Upper Saddle River, NJ: Prentice Hall (2010).

https://is.muni.cz/el/1423/podzim2017/PSY028/um/_Hair_-

Multivariate data_analysis_7th_revised.pdf

13. Z. Tohidinia, M. Haghighi, Business Strategy Series, 12,5:242-256(2011).

https://www.emerald.com/insight/content/doi/10.1108/17515631111166889/full/html 